\title{
Analisis Aktivitas Ekonomi Masyarakat Dan Nilai Ekonomi Daerah Aliran Sungai Saat Terdampak Pandemi COVID-19 Di Kelurahan Panamas Kecamatan Selat Kabupaten
}

\author{
Rinto Alexandro ${ }^{1}$, Windy Utami Putri ${ }^{2}$, Merisa Oktaria ${ }^{3}$ \\ Pendidikan Ekonomi, FKIP Universitas Palangka Raya \\ *Correspondence author: rinto.alexandro@fkip.upr.ac.id Tel.: +6282231071000
}

\begin{abstract}
This study reveals about phenomena in society using descriptive methods. Problems in society will be studied and illustrated. Through this descriptive method, the researcher wants to describe the phenomenon about the research object so that he will find scientific truths about the phenomena that occur in the research object.
\end{abstract}

Keywords: Community Economy, Economic Value, Covid-19

\begin{abstract}
Abstrak: Penelitian ini mengungkap tentang fenomena di masyarakat dengan menggunakan metode deskriptif. Masalah dalam masyarakat akan dipelajari dan dibuat gambarannya. Melalui metode deskriptif ini peneliti ingin menggambarkan fenomena tentang objek penelitian sehingga akan menemukan kebenaran ilmiah tentang fenomena yang terjadi pada objek penelitian tersebut.
\end{abstract}

Kata Kunci: Ekonomi Masyarakat, Nilai Ekonomi, Covid-19

\section{Pendahuluan}

Manusia dan lingkungan merupakan sebuah hubungan yang tidak dapat terpisahkan. Hubungan timbal balik terjadi dengan adanya pembangunan yang membutuhkan lingkungan dan lingkungan dipengaruhi oleh cara pengelolaan manusia. Pemenuhan kebutuhan hidup untuk bisa hidup sejahtera dilakukan manusia dengan memanfaatkan lingkungannya. Manusia berperan aktif dalam pengelolaan sumber daya alam yang dianggap perlu. Semakin bertambahnya jumlah penduduk maka kebutuhannya akan semakin meningkat pula. Hal ini berpengaruh besar terhadap pengelolaan sumber daya alam yang akan semakin meningkat. Sumber daya alam di Kalimantan tengah memiliki kekayaan yang sangat beragam. Hal ini yang harus terjaga demi keberlangsungan hidup sumber daya manusia maupun sumber daya alam itu sendiri. Seperti yang dikatakan oleh Tjilik Riwut dalam Laporan Studi oleh Institute for Sustainable Borneo bahwa : Kalau pembaca naik pesawat terbang di atas Kalimantan, kelak akan Nampak hutan rimba belantara yang luas-luas yang di sana tentulah banyak sekali binatang-binatang yang buas-buas sebagai penghuni hutan tersebut seperti Macan Dahan (Hangkulih bahasa Dayak), orang hutan (Kahiu Alas) Beruang, Landak, Ular Sawah, yang besar-besar, Buaya di sungai-sungai yang tidak kurang bahayanya bagi manusia. Betul hutannya luas-luas! Tetapi percayalah di situ kelak kekayaan alamnya akan menjadi Gudang Negara. Istilah "Gudang Negara" yang dipakai mengharapkan kekayaan alam di Kalimantan Tengah akan tetap terjaga secara berkelanjutan. Sumber daya alam yang dimiliki Kalimantan Tengah bisa mensejahterakan generasi yang akan datang. Hal ini sangat berhubungan dengan cara pengelolaan sumber daya alam oleh masyarakat Kalimantan Tengah. Masyarakat Kalimantan Tengah sebagian bermukim di daerah aliran sungai. Hubungan timbal balik yang dilakukan masyarakat di daerah aliran sungai tentu saja akan berhubungan langsung dengan lingkungannya yaitu daerah aliran sungai. Pengelolaan daerah aliran sungai menjadi cara masyarakat untuk memenuhi kebutuhan hidup, kondisi DAS tersebutpun akan dipengaruhi oleh masyarakatnya. Seperti yang tertuang dalam Peraturan Pemerintah RI No 37 Tahun 2012 yaitu: Pengelolaan DAS adalah upaya manusia dalam mengatur hubungan timbal balik antara sumber day alam dengan manusia di dalam DAS dan segala aktivitasnya, agar terwujud kelestraian dan keserasian ekosistem serta meningkatnya kemanfaatan 
sumber daya alam bagi manusia secara berkelanjutan. Setiap daerah aliran sungai memiliki aktivitas ekonomi yang beragam. Begitu pula di Kelurahan Panamas, Kecamatan Selat Kabupaten Kapuas yang bermukim di daerah aliran sungai Kapuas. Pemenuhan kebutuhan mereka lakukan dengan melakukan aktivitaas di daerah aliran sungai. Sejalan dengan hasil penelitian dari Sudaryono dalam publikasi artikel ilmiah yang mengatakan bahwa: "Pengelolaan DAS harus dilakukan melalui satu sistem yang dapat memberikan produktivitas lahan yang tinggi, kelestarian DAS dan peningkatan kesejahteraan masyarakat."

Daerah aliran sungai Kapuas di Kelurahan Panamas memiliki nilai ekonomi yang seharusnya dapat dimanfaatkan oleh masyarakat di sekitarnya. Output dari DAS seperti air adalah kebutuhan manusia yang paling mendasar. Air belum dapat digantikan dengan benda lainnya dalam rangka pemenuhan kebutuhan. Banyak sektor kehidupan masyarat DAS Kelurahan Panamas yang bergantung dengan keberadaan air di sungai Kapuas. Berdasarkan hasil pengamatan di Kelurahan Panamas, Kecamatan Selat, Kabupaten Kapuas bahwa wilayah ini masuk dalam zona merah saat pandemi Covid-19. Hal ini sangat berdampak pada seluruh kegiatan yang ada di masyarakat Kelurahan Panamas, salah satunya kegiatan perekonomian. Seperti yang dikatakan oleh Plt. Lurah Panamas Ahmad Gazali dalam borneOnews.co.id bahwa: “...dampak Covid-19 ini sangat mematikan dari semua kegiatan baik dalam segi perdagangan, pertanian, buruh harian lepas, dan lain-lain." Aktivitas ekonomi masyarakat Kelurahan Panamas menurun dikarenakan pandemi Covid-19 sehingga mempengaruhi pendapatan masyarakat. Masyarakat sulit memperoleh pendapatan seperti jumlah pendapatan ketika dalam situasi dan keadaan normal. Tujuan khusus dari penelitian ini adalah sebagai berikut: 1) Untuk mengetahui aktivitas ekonomi masyarakat DAS Kapuas saat terdampak pandemi Covid-19 di Kelurahan Panamas. 2) Untuk mengidentifikasi masalah ekonomi masyarakat DAS Kapuas saat terdampak pandemi Covid-19 di Kelurahan Panamas. 3) Untuk mengetahui potensi pengembangan nilai ekonomi DAS Kapuas saat terdampak pandemi Covid-19 di Kelurahan Panamas.

\section{Aktivitas Ekonomi Masyarakat}

Semua kegiatan manusia (perseorangan, perusahaan dan masyarakat) untuk memproduksi barang dan jasa maupun mengkonsumsi yang ditujukan kepada usaha untuk memehuni segala keinginan yang tidak terbatas dengan menggunakan sumber-sumber daya yang serba terbatas dinamakan aktivitas ekonomi. (Sugiarto, dkk:2007).

Secara umum, aktivitas ekonomi yang dilakukan manusia dapat digolongkan menjadi tiga jenis, yaitu: 1) Golongan pertama yaitu memproduksi berbagai jenis barang dan jasa, 2) Golongan kedua yaitu mendistribusikan barang atau jasa yang sudah dihasilkan, 3) Golongan ketiga yaitu mengonsumsi/memakai barang.

Aktivitas ekonomi masyarakat biasanya erat hubungannya dengan sumber daya alam di lingkungannya, misalnya:

1) Masyarakat desa yang tinggal di daerah subur biasanya bermata pencaharian sebagai petani

2) Masyarakat yang tinggal di daerah perkebunan biasanya bekerja di perkebunan

3) Masyarakat yang tinggal di pantai bisanya menjadi nelayan

4) Masyarakat yang tinggal di daerah objek wpariwisata biasanya bermata pencaharian sebagai pemandu wisata, menjual souvenir, atau berdagang makanan

5) Masyarakat yang tinggal di daerah industri pada umumnya menjadi pekerja pabrik, berdagang makanan, mengontrakkan rumah untuk pekerja pabrik, serta usaha angkutan

6) Masyarakat yag daerahnya memiliki sumber daya alam yang berpotensi sebagai bahan kerajinan biasanya menajdi pengrajin. (Rachmat : 2010)

Jenis usaha ekonomi yang ada di masyarakat yaitu:

1) Bidang Pertanian

2) Bidang Peternakan

3) Bidang Perikanan

4) Bidang Jasa

5) Bidang Perdagangan 
6) Bidang Industri

Untuk berlangsungnya aktivitas ekonomi diperlukan tiga unsur, yaitu:

1) Keinginan Manusia

Keinginanan manusia timbul dari kebutuhannya. Secara umum keinginana manusia mempunyai dua ciri. Ciri pertama keinginan manusai beraneka ragam. Ciri kedua keinginan manusia tanpa batas.

2) Sumber-sumber Daya

3) Cara-cara Berproduksi (techniques of production)

\section{Nilai Ekonomi}

Nilai ekonomi yang terkandung dalam suatu sumber daya alam dibagi menjadi:

1) Nilai Guna

a. Nilai manfaat (use value)

a) Nilai Manfaat Langsung (direct use value)

Pengeluaran berupa barang atau jasa yang dikandung sumber daya yang dapat dimanfaatkan secara langsung. Nilai manfaat juga dapat berupa potensi pemanfaatan di mada depan sepanjang sumber daya tidak mengalami kemusnahan, nilai ini disebut nilai manfaat pilihan (NMP).

b) Nilai Manfaat Tidak Langsung (indirect use value)

Barang dan jasa tersedia karena keberadaan sumber daya, tetapi tidak secara langsung diambil dari sumber daya alam tersebut.

b. Bukan nilai manfaat (non-use value).

a) Nilai Pewarisan (bequest value)

Nilai berhubungan dengan perlindungan atau pengawetan suatu sumber daya agar dapat diwariskan kepada generasi berikutnya untuk dimanfaatkan.

b) Nilai Keberadaan (existence value)

Nilai keberadaan (NK) adalah nilai keberadaan suatu sumber daya alam yang terlepas dari manfaat yang dapat diambil dari padanya. Nilai ini lebih terkait dengan nilai kultur atau religious yang melihat hak hidup dari setiap komponen sumber dayaalam.

2) Nilai Fungsional

\section{Daerah Aliran Sungai}

Daerah aliran sungai merupakan ekosistem, dimana unsur organisme dan llingkungan biofisik serta unsur kimia berinteraksi secara dinamis dan di dalamnya terdapat keseimbangan inflow dan outflow dari material dan energi. Selain itu pengelolaan DAS dapat disebutkan merupakan suatu bentuk pengembangan wilayah yang menempatkan DAS sebagai suatu unit pengelolaan sumber daya alam (SDA) yang secara umum untuk mencapai tujuan peningkatan produksi pertanian dan kehutanan yang optimum dan berkelanjutan (lestari) dengan upaya menekan kerusakan seminimum mungkin agar distribusi aliran air sungai yang berasal dari DAS dapat merata sepanjang tahun. (Direktorat Kehutanan dan Konservasi Sumberdaya Air). DAS (Daerah Aliran Sungai) adalah daerah yang di batasi oleh punggungpunggung gunung dimana air hujan yang jatuh pada daerah tersebut akan di tampung oleh punggung gunung tersebut dan akan dialirkan melalui sungaisungai kecil menuju sungai utama (Asdak, 2014). Peraturan Pemerintah No 37 tahun 2012 menyatakan bahwa Pengelolaan DAS merupakan upaya manusia dalam mengatur hubungan timbal balik antara sumber daya alam dengan manusia di dalam DAS dan segala aktifitasnya, agar terwujud kelestarian dan keserasian ekosistem serta meningkatnya kemanfaatan sumberdaya alam bagi manusia secara berkelanjutan. Definisi DAS berdasarkan fungsi DAS dibagi dalam beberapa batasan, yaitu pertama DAS bagian hulu didasarkan pada fungsikonservasi yang dikelola untuk mempertahankan kondisi lingkungan DAS agar tidak terdegradasi. Fungsi konservasi dapat diindikasikan dari kondisi tutupan vegetasi lahan DAS, kualitas air, kemampuan menyimpan air (debit), dan curah hujan. Kedua, DAS bagian tengah didasarkan pada fungsi pemanfaatan air sungai yang dikelola untuk dapat memberikan manfaat bagi kepentingan sosial dan ekonomi, yang antara lain dapat diindikasikan dari kuantitas air, kualitas air, kemampuan menyalurkan air, dan ketinggian muka air tanah serta terkait 
pada prasarana pengairan seperti pengelolaan sungai, waduk, dan danau. Ketiga, DAS bagian hilir didasarkan pada fungsi pemanfaatan air sungai yang dikelola untuk memberikan manfaat bagi kepentingan sosial dan ekonomi yang diindikasikan memalui keantitas dan kualitas air, kemampuan menyalurkan air, ketinggian curah hujan, dan terkait untuk kebutuhan pertanian, air bersih, serta pengelolaan air limbah. Definisi dari Asdak (2010) yaitu Daerah Aliran Sungai (DAS) sebagai suatu wilayah daratan yang secara topografik dibatasi oleh punggung-punggung gunung yang menampung dan menyimpan air hujan untuk kemudian menyalurkannya ke laut melalui sungai utama. Wilayah daratan tersebut dinamakan daerah tangkapan air (DTA atau catchment area) yang merupakan suatu ekosistem daerah unsur utamanya terdiri atas sumberdaya alam (tanah, air, dan vegetasi) dan sumberdaya manusia sebagai pemanfaat sumberdaya alam.

\section{Pandemi Covid-19}

SARS-CoV-2 atau COVID 2 merupakan virus dari jenis beta coronavirus yang dapat menyebabkan gangguan pernafasan ringan hingga berat. Virus COVID-19 memiliki tingkat penularan yang lebih tinggi dibandingkan SAR-CoV ataupun MERS. Masa inkubasi virus adalah 0 24 hari dengan rata-rata dari gejala pertama hingga kematian adalah 3-14 hari. Namun masa ini bervariasi dan akan semakin cepat bila usia penderita semakin tua.

\section{METODE}

\section{Pendekatan dan Jenis Penelitian}

Penelitian ini mengungkap tentang fenomena di masyarakat dengan menggunakan metode deskriptif. Masalah dalam masyarakat akan dipelajari dan dibuat gambarannya. Melalui metode deskriptif ini peneliti ingin menggambarkan fenomena tentang objek penelitian sehingga akan menemukan kebenaran ilmiah tentang fenomena yang terjadi pada objek penelitian tersebut.

\section{Tahap-tahap Penelitian}

Tahap-tahap penelitian sangat diperlukan agar pada praktiknya penelitian kualitatif ini dapat dilaksanakan dengan baik. Setiap langkah di dalam tahapan-tahapan penelitian termuat hal yang harus dipatuhi seperti berikut.

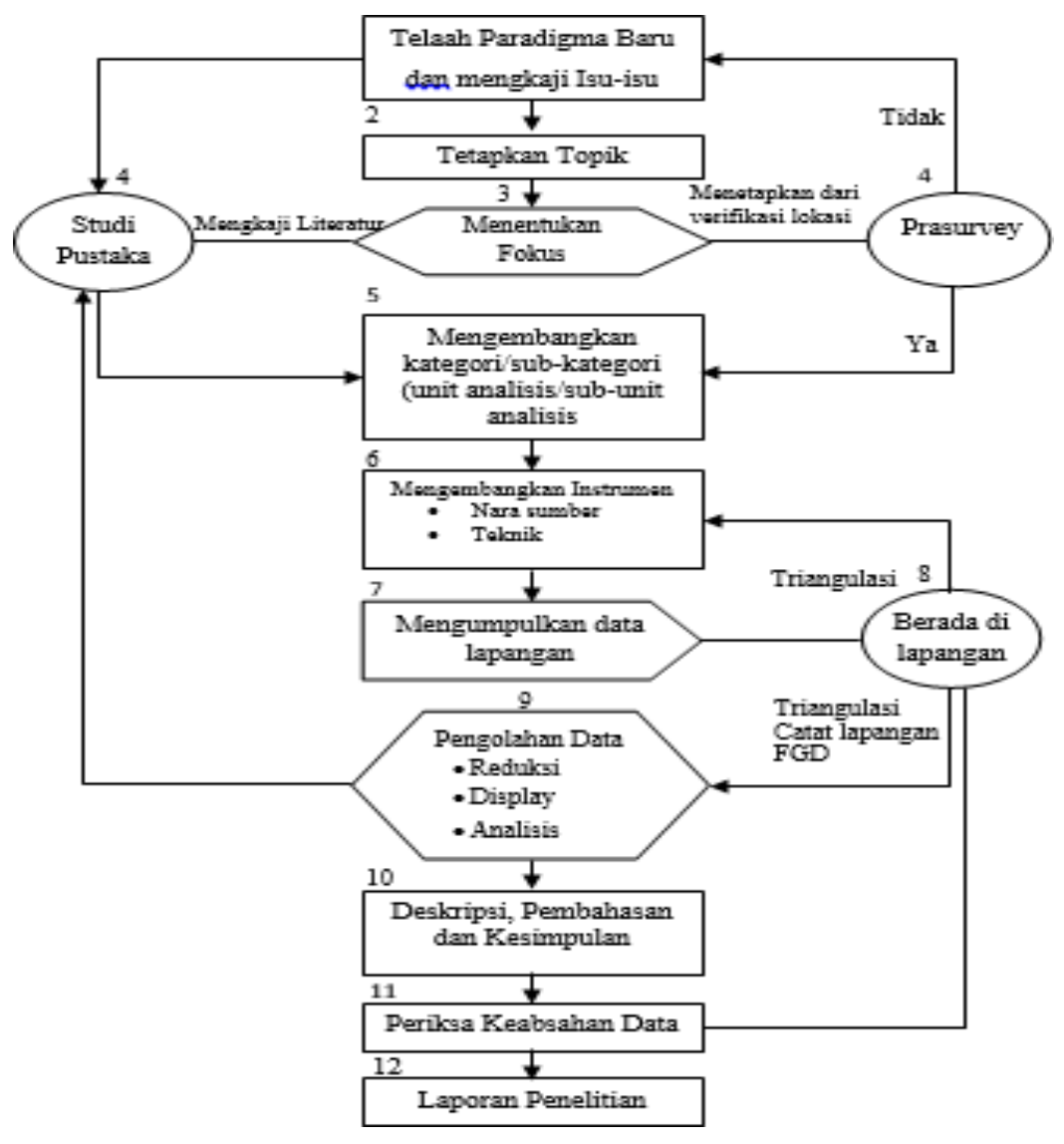


Gambar 1. Alur Tahap Penelitian

Setiap langkah tersebut yang dilakukan adalah sebagai berikut:

1. Memilih Topik Kajian

Memilih topik dapat dilihat pada masalah dan fenomena yang nyata dan terus menerus berlangsung. Semua peneiti dalam penelitian ini memperhatikan peristiwa yang terjadi pada orang-orang di sekitar untuk menemukan dan memilih topik. Ada banyak fenomena yang terjadi dan peneliti memilih topik kajian tentang Perekonomian. Fenomena yang paling menarik yaitu terjadinya pandemi Covid-19 sehingga peneliti ingin ikut memberikan solusi tentang masalah yang sedang terjadi. Langkah pemilihan topik kajian ini sesuai dengan yang dikatakan oleh Djam'an Satori dan Aan Komariah (2010:85) bahwa: "Peristiwa-peristiwa yang diamati dalam konteks kegiatan orang-orang/organisasi dapat menjadi inspirasi menemukan topik yang akan dikaji".

2. Menentukan Fokus Inquiri

Setelah menemukan topik kajian, langkah kedua yang dilakukan adalah menentukan fokus penelitian. Pada tahap ini peneliti mengkaji topik yang telah dipilih yaitu Perekonomian. Mengkaji topik dilakukan mendalam dengan memperhatikan paradigma perekonomian masyarakat yang sedang ramai diperbincangkan dan perkembangan perekonomian yang terjadi pada saat sekarang, khususnya ketika pandemic Covid-19 ini terjadi. Penulis dalam penelitian ini mengambil focus pada aktivitas ekonomi masyarakat dan nilai ekonomi daerah aliran sungai saat terdampak pandemi covid-19.

3. Melakukan Survey Pendahuluan

Survey pendahuluan yaitu dengan memilih lokasi penelitian yang digunakan untuk sumber data. Lokasi penelitian yang dipilih harus sesuai dengan permasalahan yang diangkat dalam penelitian. Melalui survey lapangan peneliti dalam penelitian ini melakukan penjajakan, mengenal lapangan dari segi situasi, kondisi, latar dan konteksnya. Anggota peneliti melakukan survey pendahuluan lokasi.

4. Mengkaji Literatur

Mengkaji literatur dilakukan sambil melakukan survey pendahuluan. Sementara angora peneliti melakukan survey pendahuluan, ketua peneliti pun mengkaji literatur yang ada. Kajian literatur tersebut ialah agar di dalam penelitian peneliti tidak melakukan penelitian yang tidak ada hubungannya dengan penelitian.

5. Mengembangkan Kategori Sub Kategori/Unit Analisis Sub Unit Analisis Setelah didapat fokus inquiri yang sesuai dengan lapangan maka selanjutnya dilakukan pengembangan kategori sub kategori atau unit analisis sub unit analisis. Semua peneliti berdiskusi dalam mengembangkan kategori sub kategori ini.

6. Mengembangkan Instrumen

Setelah mengembangkan kategori sub kategori yang dilakukan semua peneliti kemudian adalah mengembangkan instrumen. Peneliti di dalam penelitian kualitatif merupakan instrument utama sebagai pengumpul data (instrument). Tehnik yang digunakan dalam membantu mengumpulkan data adalah wawancara mendalam, observasi, studi dokumenter. Instrument wawancara mendalam dikembangkan oleh Ketua Peneliti yaitu Rinto Alexandro, instrument observasi dikembangkan oleh anggota peneliti yaitu Windy Utami Putri, dan instrument studi documenter dikembangkan oleh anggota peneliti yaitu Merisa Oktaria.

7. Mengumpulkan Data

a. Masuk Lapangan

Ketika masuk lapangan semua peneliti mempersiapkan diri secara fisik, psikologis maupun mental.

b. Berada di Lapangan

Ketika berada di lapangan semua peneliti selain memahami teknik penelitian juga harus bisa beradaptasi dengan lingkungan yang ada di lapangan.

c. Memilih dan Memanfaatkan Informan 
Semua peneliti berdiskusi untuk memilih informan yang memenuhi syarat menjadi informan. Selain memilih informan, peneliti juga memanfaatkan informan agar mendapatkan banyak informasi yang terjaring. Seorang informan harus mempunyai banyak pengalaman tentang latar penelitian selain itu Satori dan Aan Komariah (2010:94) berpendapat mengenai persyaratan seorang informan itu ialah: Seorang informan harus jujur, taat pada janji, patuh pada peraturan, suka berbicara, tidak termasuk anggota salah satu kelompok yang mempunyai konflik dalam latar penelitian, dan mempunyai pandangan tertentu tentang peristiwa yang terjadi.

d. Triangulasi

Tujuan berada di lapangan ialah untuk mengeksplorasi data/informasi yang banyak dan akurat. Triangulasi diperlukan agar informasi yang diperoleh memenuhi syarat objektivitas. Triangulasi data ini dilakukan semua peneliti.

e. Mencatat Data/Informasi Lapangan

Selama penggunaan teknik semua peneliti membuat catatan agar informasi tidak terabaikan. Peneliti senantiasa membawa catatan ketika melakukan penelitian.

f. Focus Group Discussiun

Pada kegiatan ini semua peneliti mengundang para informan kunci untuk mendiskusikan konsep berkaitan dengan data yang diungkap.

8. Pengolahan Data

Langkah yang dilakukan selanjutnya adalah pengolahan data. Pengolahan data dilakukan dengan langkah yaitu: (1) reduksi data; (2) display data; (3) analisis data. Pengolahan data ini dilakukan oleh semua peneliti dengan kerjasama melalui diskusi.

9. Mendeskripsikan dan Membahas Hasil Penelitian

Setelah pengolahan data semua peneliti mendeskripsikan hasil penelitian dan membahas hasil penelitian. Hal ini dilakukan dengan saling berdiskusi.

10. Kesimpulan

Data yang sudah diproses kemudian disimpulkan oleh semua peneliti menjadi suatu kesimpulan.

11. Keabsahan Penelitian

Keabsahan hasil penelitian dilakukan semua peneliti dengan masing-masing croscek terhadap prosedur penelitian dan terhadap substansi penelitian.

12. Laporan Hasil Penelitian

Setelah semua langkah dilakukan maka peneliti menulis laporan hasil penelitian. Laporan ini ditulis dengan tetap diskusi antara semua peneliti dalam penelitian ini.

\section{Sumber Data}

Berdasarkan cara memperolehnya, penelitian ini menggunakan data primer yang menggunakan tehnik Pengambilan Sampel yaitu Purposive Sampling. Sumber data dalam penelitian ini ialah peneliti, Informan yang terdiri dari Lurah 1 orang, Tokoh Masyarakat Kelurahan Panamas 2 orang, masyarakat Kelurahan Panamas berjumlah 6 orang.

\section{Tehnik Pengumpulan Data}

Penelitian ini akan mengumpulkan data tentang masalah yang akan diteliti. Tehnik peneliti dalam pengumpulan data tersebut ialah:

1) Observasi. Penelitian ini dalam megumpulkan data melalui pengamatan secara langsung terhadap keaadaan yang ada di Kelurahan Panamas, Kecamatan Selat, Kabupaten Kapuas.

2) Wawancara mendalam. Wawancara mendalam ialah mendapatkan data melalui cara langsung bertemu dan bertatap muka kemudian melakukan dialog antara peneliti dan informan.

3) Studi dokumenter. Studi dokumenter ialah pengumpulan informasi dengan cara mengumpulkan data yang berbentuk dokumentasi yang berkaitan dengan aktivitas ekonomi masyarakat dan nilai ekonomi daerah aliran sungai saat terdampak pandemi covid-19 di Kelurahan Panamas, Kecamatan Selat, Kabupaten Kapuas.

\section{Teknik Analisis Data}


Teknik analisis data yang digunakan dalam penelitian ini adalah Model Miles dan Huberman. Kegiatan yang dilakukan dalam analisis data ini adalah Reduksi Data (Data Reduction), Penyajian Data (Data Display), Penarikan Kesimpulan/Verifikasi (Conclusion Drawing/Verification). Berikut ini adalah langkah-langkah analisis dengan Model Milles dan Huberman yang akan digunakan dalam penelitian ini ditunjukan dengan gambar .

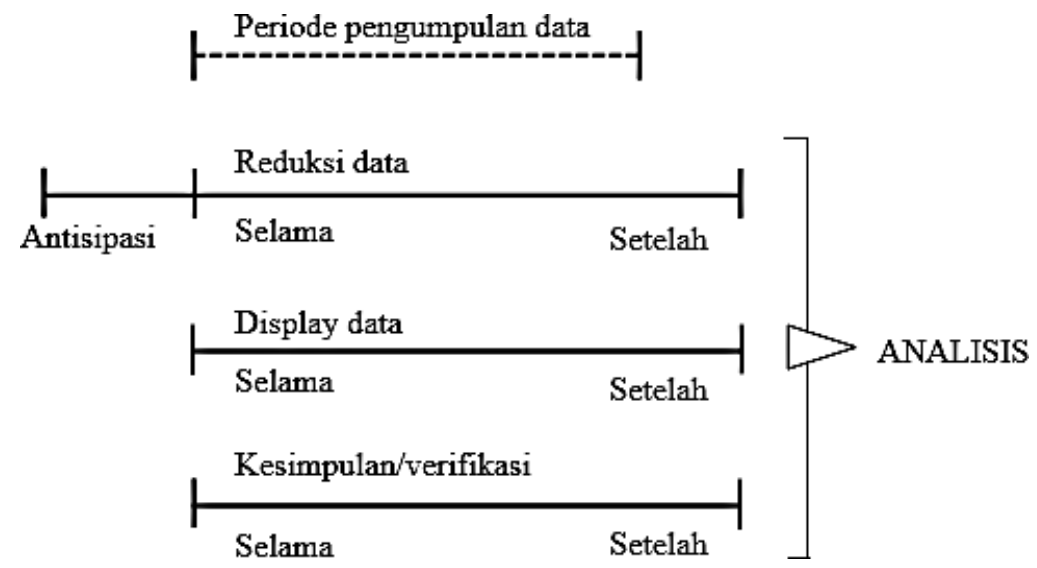

Gambar 2. Langkah-langkah Analisis dengan Model Milles dan Huberman

Teknik Triangulasi digunakan dalam penelitian ini untuk menguji kredibilitas data yang didapatkan. Pengecekan data dari informan yang digunakan dalam penelitian ini adalah Triangulasi Sumber dan Triangulasi Teknik.

\section{HASIL DAN PEMBAHASAN}

\section{Hasil Penelitian}

Berikut ini merupakan hasil penelitian sesuai hasil observasi dan pengumpulan data di lapangan yang juga didukung oleh data dari BPS.

\section{POPULATION}

\section{Tabel 5.2 Jumlah Penduduk dan Rasio Jenis Kelamin Penduduk Table menurut Desa/Kelurahan di Kecamatan Selat, 2019 \\ Population and Population Sex Ratio by Village/Kelurahan in Selat Subdistrict, 2019}

\begin{tabular}{|c|c|c|c|c|c|}
\hline & \multirow{2}{*}{$\begin{array}{l}\text { Desa/Kelurahan } \\
\text { Village/Kelurahan }\end{array}$} & \multicolumn{3}{|c|}{$\begin{array}{l}\text { Penduduk (orang) } \\
\text { Population (person) }\end{array}$} & \multirow{2}{*}{$\begin{array}{l}\text { Rasio Jenis Kelamir } \\
\text { Sex Ratio }\end{array}$} \\
\hline & & $\begin{array}{l}\text { Laki-laki } \\
\text { Male }\end{array}$ & $\begin{array}{l}\text { Perempuan } \\
\text { Female }\end{array}$ & $\begin{array}{c}\text { Jumlah } \\
\text { Total }\end{array}$ & \\
\hline & (1) & (2) & (3) & (4) & (5) \\
\hline 1. & Murung Keramat & 2079 & 1867 & 3946 & 111 \\
\hline 2. & Selat Hilir & 4725 & 4707 & 9432 & 100 \\
\hline 3. & Selat Tengah & 7284 & 7370 & 14654 & 99 \\
\hline 4. & Selat Hulu & 6950 & 6802 & 13752 & 102 \\
\hline 5. & Selat Dalam & 6270 & 6038 & 12308 & 104 \\
\hline 6. & Pulau Telo & 1920 & 1836 & 3756 & 105 \\
\hline 7. & Panamas & 813 & 776 & 1589 & 105 \\
\hline 8. & Selat Barat & 3236 & 3202 & 6438 & 101 \\
\hline 9. & Selat Utara & 1987 & 1902 & 3889 & 104 \\
\hline 10. & Pulau Telo Baru & 790 & 782 & 1572 & 101 \\
\hline & Selat & 36054 & 35282 & 71336 & 102 \\
\hline
\end{tabular}

Sumber/Source. Dinas Kependudukan dan Pencatatan Sipil Kabupaten Kapuas/Population and Civil Registration Office of Kapuos Regency 
Berdasarkan Gambar 1 maka diketahui bahwa jumlah penduduk yang ada di Kelurahan Panamas berjumlah 1.589 jiwa, sehingga hal ini juga menjadi suatu gambaran bahwa dengan jumlah kepadatan penduduk demikian perekonomian dan kesejahteraan masyarakat di Kelurahan Panamas cukup kecil dibandingkan sembilan kelurahan lainnya. Sehingga kegiatan perekonomian yang ada di Panamas pun cenderung relatif tidak variatif, dibuktikan dengan rata-rata pekerjaan penduduk Panamas adalah seorang Petani.

KEADAAN GEOGRAFI

\begin{tabular}{|c|c|c|c|}
\hline \multicolumn{2}{|c|}{$\frac{\text { Tabel }}{\text { Table }}$} & \multicolumn{2}{|c|}{$\begin{array}{l}\text { Luas Daerah menurut Desa/Kelurahan di Kecamatan } \\
\text { Selat, } 2019 \\
\text { Total Area by Village/Kelurahan in Selat Subdistrict, } 2019\end{array}$} \\
\hline & $\begin{array}{l}\text { Desa/Kelurahan } \\
\text { Village/Kelurahan }\end{array}$ & $\begin{array}{c}\text { Luas }^{1}\left(\mathbf{k m}^{2}\right) \\
\text { TotalArea }(\text { square.km) }\end{array}$ & $\begin{array}{l}\text { Persentase terhadap Luas } \\
\text { Kecamatan } \\
\text { Percentage to Subdistrict's Area }\end{array}$ \\
\hline & (1) & (2) & (3) \\
\hline 1. & Murung Keramat & 7,74 & 12,20 \\
\hline 2. & Selat Hilir & 3,04 & 4,79 \\
\hline 3. & Selat Tengah & 1,61 & 2,54 \\
\hline 4. & Selat Hulu & 4,76 & 7,50 \\
\hline 5. & Selat Dalam & 5,99 & 9,44 \\
\hline 6. & Pulau Telo & 1,47 & 2,32 \\
\hline 7. & Panamas & 8,41 & 13,26 \\
\hline 8. & Selat Barat & 5,25 & 8,28 \\
\hline 9. & Selat Utara & 12,68 & 19,99 \\
\hline 10. & Pulau Telo Baru & 12,48 & 19,68 \\
\hline
\end{tabular}

Catatan/Note: $\quad$ 'Berdasarkan Peraturan Menteri Dalam Negei Nomor 137 Tahun 2017 tanggal 29 Desember 2017/Based on Minister of Home Affairs Regulation Number 137/2018, December 29, 2017

Sumber/Source. Kementerian Dalam Negeri/Ministry of Home Affairs

Berdasarkan Gambar 2 diketahui bahwa luas daerah Panamas adalah seluas $8.41 \mathrm{~km}^{2}$ atau sebesar 13,26 \% dari Kecamatan Selat, jika dilihat dari data geografi maka luas daerah dan kepadatan penduduk yang ada di Kelurahan Panamas tidak seimbang, hal ini menunjukan pemerataan daerah yang kurang optimal sehingga kegiatan perekonomian yang seharusnya bisa berkembang justru menjadi kurang optimal.

Dengan melihat luas dan kepadatan penduduk yang ada di Kelurahan Panamas, tim peneliti pun melakukan crosscheck ke Lapangan. Menurut kami Kelurahan Panamas memiliki Daerah yang mampu dioptimalkan lebih lagi karena dengan luas Daerah demikian seharusnya mampu memiliki kegiatan perekonomian yang lebih variatif lagi dan memngembangkan Daerah Aliran Sungai yang ada di sekitar Panamas untuk dapat menjadi sumber ekonomi yang terarah bagi Kelurahan Panamas. 
Edunomics Journal, Vol. 2 (1): page 43-55, Januari 2021 received: 2020-12-12; Accepted: 2021-01-04 p-ISSN: 2722-6697; e-ISSN: 2723-553X

\section{SOCIAL AND WELFARE}

Tabel 2.3.11 Banyaknya Sarana dan Prasarana Ekonomi menurut Table Desa/Kelurahan dan Jenisnya di Kecamatan Selat, 2019

Number of Economic Facilities and Infrastructure by Village/Kelurahan and Its Type in Selat Subdistrict, 2019

\begin{tabular}{|c|c|c|c|c|c|}
\hline & $\begin{array}{l}\text { Desa/Kelurahan } \\
\text { Village/Kelurahan }\end{array}$ & $\begin{array}{c}\text { Kelompok } \\
\text { Pertokoan } \\
\text { Shopping } \\
\text { Complex }\end{array}$ & $\begin{array}{c}\text { Pasar dengan } \\
\text { Bangunan } \\
\text { Permanen } \\
\text { Marketin Permanent } \\
\text { Building }\end{array}$ & $\begin{array}{c}\text { Pasar dengan } \\
\text { Bangunan Semi } \\
\text { Permanen } \\
\text { Marketin Semi } \\
\text { Permanent Buildings }\end{array}$ & $\begin{array}{c}\text { Pasar Tanpa } \\
\text { Bangunan } \\
\text { Market without } \\
\text { Permanent } \\
\text { Building }\end{array}$ \\
\hline \multicolumn{2}{|r|}{ (1) } & (2) & (3) & (4) & (5) \\
\hline 1. & Murung Keramat & - & - & - & 3 \\
\hline 2. & Selat Hilir & 14 & 1 & 1 & 1 \\
\hline 3. & Selat Tengah & 6 & 3 & 3 & 1 \\
\hline 4. & Selat Hulu & - & - & - & 1 \\
\hline 5. & Selat Dalam & 4 & - & - & 1 \\
\hline 6. & Pulau Telo & - & - & - & 1 \\
\hline 7. & Panamas & C & - & - & 1 \\
\hline 8. & Selat Barat & 4 & - & - & 2 \\
\hline 9. & Selat Utara & - & - & - & 2 \\
\hline \multirow[t]{2}{*}{10.} & Pulau Telo Baru & - & - & - & - \\
\hline & Selat & 28 & 4 & 4 & 13 \\
\hline
\end{tabular}

\section{SOSIAL DAN KESEJAHTERAAN RAKYAT}

Lanjutan Tabel/Continued Table 2.3.11

\begin{tabular}{|c|c|c|c|c|}
\hline & $\begin{array}{l}\text { Desa/Kelurahan } \\
\text { Village/Kelurahan }\end{array}$ & $\begin{array}{l}\text { Minimarket/Swalayan' } 1 \\
\text { Mini Market }\end{array}$ & $\begin{array}{l}\text { Toko/Warung } \\
\text { Kelontong } \\
\text { Shop/Grocery Store }\end{array}$ & $\begin{array}{c}\text { Restoran/Rumah } \\
\text { Makan } \\
\text { Restaurant/Food Stal }\end{array}$ \\
\hline & (1) & (6) & (7) & (8) \\
\hline 1. & Murung Keramat & - & - & - \\
\hline 2. & Selat Hilir & 2 & 99 & 13 \\
\hline 3. & Selat Tengah & 7 & 99 & 15 \\
\hline 4. & Selat Hulu & 5 & 26 & 1 \\
\hline 5. & Selat Dalam & 4 & 86 & 21 \\
\hline 6. & Pulau Telo & 1 & 6 & - \\
\hline 7. & Panamas & - & 6 & - \\
\hline 8. & Selat Barat & 2 & 70 & 5 \\
\hline 9. & Selat Utara & & 34 & 6 \\
\hline \multirow[t]{2}{*}{10.} & Pulau Telo Baru & - & 60 & 6 \\
\hline & Selat & 21 & 486 & 67 \\
\hline
\end{tabular}


Edunomics Journal, Vol. 2 (1): page 43-55, Januari 2021 received: 2020-12-12; Accepted: 2021-01-04 p-ISSN: 2722-6697; e-ISSN: 2723-553X

SOCIAL AND WELFARE

Lanjutan Tabel/Continued Table 2.3.11

\begin{tabular}{|c|c|c|c|c|}
\hline & $\begin{array}{l}\text { Desa/Kelurahan } \\
\text { Village/Kelurahan }\end{array}$ & $\begin{array}{c}\text { Warung/Kedai } \\
\text { Makanan } \\
\text { Food and BeverageStore }\end{array}$ & $\begin{array}{l}\text { Hotel } \\
\text { Hotel }\end{array}$ & $\begin{array}{c}\text { Hostel/Motel/Losmen/ } \\
\text { Wisma } \\
\text { Inn }\end{array}$ \\
\hline \multicolumn{2}{|r|}{ (1) } & (9) & (10) & $(11)$ \\
\hline 1. & Murung Keramat & 6 & - & - \\
\hline 2. & Selat Hilir & 61 & 10 & 3 \\
\hline 3. & Selat Tengah & 99 & 3 & 1 \\
\hline 4. & Selat Hulu & 48 & - & - \\
\hline 5. & Selat Dalam & 48 & 2 & 4 \\
\hline 6. & Pulau Telo & 4 & 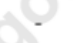 & - \\
\hline 7. & Panamas & 9 & - & - \\
\hline 8. & Selat Barat & 1 & 1 & - \\
\hline 9. & Selat Utara & 12 & - & - \\
\hline 10. & Pulau Telo Baru & 13 & - & - \\
\hline \multicolumn{2}{|r|}{ Selat } & 301 & 16 & 8 \\
\hline catat & רotes. & otal Areale. & esquare & \\
\hline Sumber & r/Source. & Potensi Desa (Podes) 2019/4 & didonesia, & tential Data Collection 2019 \\
\hline
\end{tabular}

PERTANIAN, KEHUTANAN, PETERNAKAN, DAN PERIKANAN

\subsection{PERKEBUNAN}

ESTATE CROPS

Tabel 3.2.1 Luas Areal Tanaman Perkebunan menurut Table Desa/Kelurahan dan Jenis Tanaman di Kecamatan Selat (ha), 2018 dan 2019

Planted Area of Estate Crops by Village/Kelurahan and Type of Crops in Selat Subdistrict (ha), 2018 and 2019

\begin{tabular}{|c|c|c|c|c|c|c|c|c|c|}
\hline & \multirow{2}{*}{$\begin{array}{l}\text { Desa/Kelurahan } \\
\text { Village/Kelurahan }\end{array}$} & \multicolumn{2}{|c|}{$\begin{array}{c}\text { Kelapa Sawit } \\
\text { Oil Palm }\end{array}$} & \multicolumn{2}{|c|}{$\begin{array}{l}\text { Kelapa } \\
\text { Coconut }\end{array}$} & \multicolumn{2}{|c|}{$\begin{array}{l}\text { Karet } \\
\text { Rubber }\end{array}$} & \multicolumn{2}{|c|}{$\begin{array}{l}\text { Kopi } \\
\text { Coffee }\end{array}$} \\
\hline & & 2018 & 2019 & 2018 & 2019 & 2018 & 2019 & 2018 & 2019 \\
\hline & (1) & (2) & (3) & (4) & (5) & (6) & (7) & (8) & (9) \\
\hline 1. & Murung Keramat & - & $\ldots$ & $\ldots$ & $\ldots$ & $\ldots$ & $\ldots$ & $\ldots$ & $\ldots$ \\
\hline 2. & Selat Hilir & - & $\ldots$ & ... & ... & ... & $\ldots$ & ... & ... \\
\hline 3. & Selat Tengah & - & $\ldots$ & $\ldots$ & $\ldots$ & ... & $\ldots$ & $\cdots$ & ... \\
\hline 4. & Selat Hulu & - & $\ldots$ & $\ldots$ & ... & $\ldots$ & ... & $\ldots$ & ... \\
\hline 5. & Selat Dalam & - & ... & ... & $\ldots$ & $\ldots$ & $\ldots$ & $\ldots$ & $\ldots$ \\
\hline 6. & Pulau Telo & 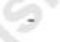 & $\ldots$ & $\ldots$ & ... & $\ldots$ & ... & $\ldots$ & ... \\
\hline 7. & Panamas & - & $\ldots$ & $\ldots$ & ... & $\ldots$ & $\ldots$ & $\ldots$ & ... \\
\hline 8. & Selat Barat & - & $\ldots$ & $\ldots$ & ... & $\ldots$ & $\ldots$ & $\ldots$ & ... \\
\hline 9. & Selat Utara & - & $\cdots$ & $\cdots$ & ... & ... & ... & $\cdots$ & $\ldots$ \\
\hline 10. & Pulau Telo Baru & - & $\ldots$ & $\ldots$ & $\ldots$ & $\ldots$ & $\ldots$ & $\ldots$ & $\ldots$ \\
\hline & Selat & - & 0,00 & 176,26 & 196,26 & 535,30 & 535,30 & 1,64 & 1,64 \\
\hline
\end{tabular}


PERTANIAN, KEHUTANAN, PETERNAKAN, DAN PERIKANAN

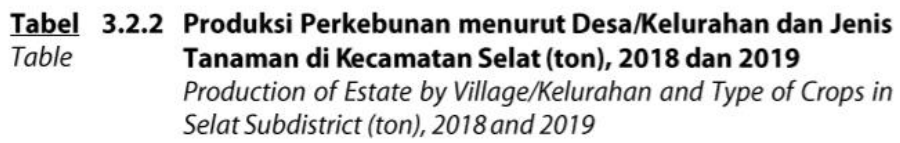

Selat Subdistrict (ton), 2018 and 2019

\begin{tabular}{|c|c|c|c|c|c|c|c|c|c|}
\hline & \multirow{2}{*}{$\begin{array}{l}\text { Desa/Kelurahan } \\
\text { Village/Kelurahan }\end{array}$} & \multicolumn{2}{|c|}{$\begin{array}{c}\text { Kelapa Sawit } \\
\text { Oil Palm }\end{array}$} & \multicolumn{2}{|c|}{$\begin{array}{l}\text { Kelapa } \\
\text { Coconut }\end{array}$} & \multicolumn{2}{|c|}{$\begin{array}{l}\text { Karet } \\
\text { Rubber }\end{array}$} & \multicolumn{2}{|c|}{$\begin{array}{l}\text { Kopi } \\
\text { Coffee }\end{array}$} \\
\hline & & 2018 & 2019 & 2018 & 2019 & 2018 & 2019 & 2018 & 2019 \\
\hline & (1) & (2) & (3) & (4) & (5) & (6) & $(7)$ & (8) & (9) \\
\hline 1. & Murung Keramat & - & $\ldots$ & ... & . & $\ldots$ & $\ldots$ & - & - \\
\hline 2. & Selat Hilir & - & $\ldots$ & $\ldots$ & $\cdots$ & $\ldots$ & $\ldots$ & - & - \\
\hline 3. & Selat Tengah & - & $\ldots$ & $\ldots$ & $\ldots$ & $\ldots$ & $\ldots$ & - & - \\
\hline 4. & Selat Hulu & - & $\ldots$ & $\ldots$ & $\ldots$ & $\ldots$ & $\ldots$ & - & - \\
\hline 5. & Selat Dalam & - & $\ldots$ & $\ldots$ & $\ldots$ & $\ldots$ & $\ldots$ & - & - \\
\hline 6. & Pulau Telo & - & $\ldots$ & $\ldots$ & $\ldots$ & $\ldots$ & $\ldots$ & - & - \\
\hline 7. & Panamas & - & ... & $\ldots$ & $\ldots$ & $\ldots$ & $\ldots$ & - & - \\
\hline 8. & Selat Barat & - & $\ldots$ & $\ldots$ & $\ldots$ & $\ldots$ & $\ldots$ & - & - \\
\hline 9. & Selat Utara & 6 & $\ldots$ & $\ldots$ & $\ldots$ & $\ldots$ & $\ldots$ & - & - \\
\hline 10. & Pulau Telo Baru & - & $\ldots$ & $\ldots$ & $\ldots$ & $\ldots$ & $\ldots$ & - & - \\
\hline & Selat & - & 0,00 & 40,25 & 128,00 & 125,50 & 197,00 & - & - \\
\hline
\end{tabular}

Demikian data di atas merupakan data pendukung yang kami susun untuk mendukung data penelitian yang telah kami lakukan.

\section{Pembahasan}

\section{Aktivitas Ekonomi Masyarakat DAS Kapuas Saat Terdampak Pandemi Covid-19 di Kelurahan} Panamas

Masyarakat Kelurahan Panamas memiliki aktivitas ekonomi yang tetap dijalani ketika masa pandemi. Aktivitas ini yaitu meliputi memproduksi berbagai jenis barang dan jasa, mendistribusikan barang atau jasa yang sudah dihasilkan, mengonsumsi/memakai barang. Hasil wawancara yang telah dilakukan dengan salah satu warga di Kelurahan Panamas yaitu Emy mengatakan bahwa pada masa pandemi ini tetap memproduksi barang seperti kerupuk dan bertani untuk menghasilkan padi. Adapun aktivitas ekonomi yang dilakukan oleh Utuh ketika diwawancarai adalah tetap mendistribusikan telur yang merupakan pekerjaan utamanya. Sedangkan Amat melakukan aktivitas ekonomi dengan menawarkan jasa sebagai penyebrang sungai (Feri penyebrangan). Observasi yang dilakukan oleh pengambil data juga mendapatkan bahwa masyarakat tetap melakukan aktivitas ekonomi pada masa pandemi akan tetapi tidak selancar ketika sebelum masa pandemi dikarenakan harus mengikuti protokol kesehatan yang telah ditetapkan oleh pemerintah.

Beberapa hal di atas sesuai seperti yang dikatakan oleh Sugaiarto, 2007 bahwa aktivitas ekonomi yang dilakukan manusia dapat digolongkan menjadi tiga jenis, yaitu: Golongan pertama yaitu memproduksi berbagai jenis barang dan jasa, golongan kedua yaitu mendistribusikan barang atau jasa yang sudah dihasilkan, golongan ketiga yaitu mengonsumsi/memakai barang. Berdasarkan data yang diperoleh dari profil Kecamatan Selat, masyarakat Kelurahan Panamas memiliki pekerjaan di bidang Pertanian, Peternakan, Perikanan, Bidang Jasa, dan Bidang Perdagangan.

\section{Masalah Ekonomi Masyarakat DAS Kapuas Saat Terdampak Pandemi Covid-19 di Kelurahan Panamas \\ Pada masa pandemi muncul masalah ekonomi yang dialami oleh masyarakat DAS di Kelurahan Panamas. Hasil penelitian menunjukkan bahwa terdapat permasalahan utama yang}


dirasakan oleh masyarakat sekitar sehubungan dengan Pandemi yaitu berkurangnya pendapatan dan terkendalanya distribusi barang dan jasa yang telah mereka hasilkan. Berkurangnya pendapatan seperti yang dikatakan oleh Emy pada saat wawancara mengungkapkan bahwa penjualan kue, kerupuk yang dibuat sendiri berkurang pembelinya dibandingkan dengan sebelum masa pandemi. Utuh juga mengatakan bahwa pendistribusian barang yang dilakukannya mengalami kendala dikarenakan terkadang dilakukan lockdown yang membuat dirinya harus berada di rumah untuk sementara waktu dan berdampak pada pendapatannya yang berkurang pula. Penyebrangan melalui feri yang dilakukan oleh Amat juga sempat mengalami penurunan pendapatan karena mnurunnya penumpang seperti siswa dan karyawan yang biasanya menyebrang tidak lagi seperti sebelum pandemi. Selain itu social distancing juga mengharuskan Amat untuk membatasi penumpangnya dalam sekali penyebrangan.

\section{Potensi Pengembangan Nilai Ekonomi DAS Kapuas Saat Terdampak Pandemi Covid-19 di Kelurahan Panamas}

Berdasarkan observasi yang dilakukan oleh pengambil data potenasi pengembangan Nilai ekonomi di Kelurahan Panamas dapat dilakukan dengan pengembangan pertanian dan peternakan yang dilakukan oleh sebagian besar dari penduduk dan pariwisata yang seharusnya lebih dikembangkan. Wawancara dengan masyarakat yaitu Emy juga mangatakan bahwa memiliki keinginan agar diberikan bantuan serta memberikan pelatihan tentang produk yang sedang dibuatnya. Pengetahuan teknik bercocok tanam yang baik sangat diperlukan untuk meningkatkan produktivitas lahan garapan masyarakat sekitar Panamas. Hasil penelitian menunjukkan bahwa pengetahuan teknik bercocok tanam yang diterapkan masyarakat selama ini bersumber dari orang tua mereka dan hasil interaksi sesama petani. Hal ini mengindikasikan bahwa teknik bercocok tanam yang diterapkan masih bersifat tradisional. Materi kegiatan penyuluhan dan pelatihan yang penting diberikan kepada masyarakat khususnya bagi masyarakat sekitar Panamas adalah bagaimana memaksimalkan pemanfaatan lahan garapan masyarakat DAS tanpa merusak wilayah DAS tersebut. Materi lainnya yang mendesak untuk diberikan ke masyarakat adalah teknik penanganan pasca panen dan pemasaran hasil usaha tani sehingga mereka tidak tergantung pada tengkulak atau pedagang pengumpul yang lebih cenderung menentukan harga di tingkat petani. Hal ini sesuai dengan yang telah diungkapkan oleh Rachmat, 2010 yang mengungkapkan bahwa: Aktivitas ekonomi masyarakat biasanya erat hubungannya dengan sumber daya alam di lingkungannya, misalnya masyarakat desa yang tinggal di daerah subur biasanya bermata pencaharian sebagai petani, masyarakat yang tinggal di daerah perkebunan biasanya bekerja di perkebunan, masyarakat yang tinggal di pantai bisanya menjadi nelayan, masyarakat yang tinggal di daerah objek wpariwisata biasanya bermata pencaharian sebagai pemandu wisata, menjual souvenir, atau berdagang makanan, masyarakat yang tinggal di daerah industri pada umumnya menjadi pekerja pabrik, berdagang makanan, mengontrakkan rumah untuk pekerja pabrik, serta usaha angkutan, masyarakat yag daerahnya memiliki sumber daya alam yang berpotensi sebagai bahan kerajinan biasanya menjadi pengrajin.

\section{Kesimpulan}

Aktivitas ekonomi tetap dijalani oleh masyarakat di Kelurahan Panamas ketika masa pandemi yaitu meliputi memproduksi berbagai jenis barang dan jasa berupa padi, sayur mayur, makanan olahan, hasil ternak, dan penyebrangan feri, mendistribusikan barang atau jasa yang sudah dihasilkan seperti telur dan bahan makanan pokok, mengonsumsi/memakai barang. Terdapat permasalahan utama yang dirasakan oleh masyarakat sekitar sehubungan dengan Pandemi yaitu berkurangnya pendapatan dan terkendalanya distribusi barang dan jasa yang telah mereka hasilkan. Pengembangan pertanian dan peternakan yang dilakukan oleh sebagian besar dari penduduk dan pariwisata yang seharusnya lebih dikembangkan.

Kegiatan pendampingan, penyuluhan dan pelatihan bagi masyarakat Kelurahan Panamas perlu ditingkatkan. Kegiatan ini diperlukan untuk meningkatkan pola pikir, pengetahuan, dan keterampilan petani serta semangat dan kreativitas petani dapat disalurkan kepada hal yang positif. 
Kegiatan-kegiatan tersebut diharapkan berdampak pada peningkatan produktifitas dan tingkat kesejahteraan masyarakat pada masa pandemi seperti sekarang ini. Untuk itu diperlukan upaya penyelesaian yang arif dan bijaksana demi keberlangsungan ekonomi masyarakat dalam rangka meningkatkan kesejahteraannya. Pihak Pemerintah sedapat mungkin menjalin komunikasi, koordinasi dan kerjasama dengan berbagai pihak seperti instansi/dinas teknis terkait, LSM, lembaga-lembaga penelitian dan Universitas. Komunikasi, koordinasi dan kerjasama para pihak tersebut diharapkan dapat membantu dalam meningkatkan kapasitas masyarakat, merumuskan solusi atas permasalahan yang dihadapi pada masa pandemi ini dan membantu dalam merumuskan model pengelolaan DAS yang efektif dan efisien.

\section{DAFTAR PUSTAKA}

Asdak, C. 2010. "Hidrologi dan Pengelolaan Daerah Aliran Air Sungai: Edisi Revisi Kelima." Gadjah Mada University Press Yogyakarta: Yogyakarta.

Asdak, C. 2014. "Hidrologi dan Pengelolaan Daerah Aliran Sungai." Gadjah Mada University Press: Yogyakarta.

Atmojo, J.T, dkk. "Definisi Dan Jalur Penularan Severe Acute Respiratory Syndrome Coronavirus 2 (Sars-Cov-2) atau Covid-19." E-Jurnal Pendidikan Kesehatan. 9.1 : 57-64, 2020.

borneOnews.co.id. 2020. Warga Kelurahan Panamas Telah Terima Bantuan Sosial Dampak Covid-19. Diakses pada 5020.

https://www.borneonews.co.id/berita/169659-warga-kelurahan-panamas- telah-terimabantuan-sosial-dampak-covid-19

Direktorat Kehutanan dan Konservasi Sumberdaya Air. "Model Pengelolaan Daerah Aliran Sungai (DAS) Terpadu." E-Jurnal BPPT. 3.2 : 1-19, 2011.

Institute for Sustainable Borneo. 2013. "Sejarah Pemanfaatan Sumber Daya Alam \& Peluang Pembangunan Berkelanjutan di Tingkat Perdesaan di KalimantanTengah."https://tnsebangau.files.wordpress.com/2018/03/lapora $\quad \underline{\text { n-isb- }}$ sejarah-psda-dan-peluang-pembangunan-berkelanjutan-di-kalteng- 2013.pdf

Komariah, A \& Satori, D. 2010. Metodologi Penelitian Kualitatif. Alfabeta: Bandung.

Miles, M.B, Huberman, A.M, \& Saldana, J. 2014. Qualitative Data Analysis, A Methods Sourcebook, Edition 3. USA: Sage Publications. Terjemahan Tjetjep Rohindi Rohidi, UI-Press.

Pahan, I. 2006. Kelapa Sawit : Manajemen Agribisnis dari Hulu Hingga Hilir. Penebar Swadaya : Bogor.

Peraturan Pemerintah Ri Nomor 37 Tahun 2012 Tentang Pengelolaan Daerah Aliran Sungai.

Rachmat. 2010. Ringkasan Pengetahuan Sosial. Grasindo : Jakarta.

Sudaryono. "Pengelolaan Daerah Aliran Sungai (DAS) Terpadu, Konsep Pembangunan Berkelanjutan." E-Jurnal Teknologi Lingkungan BPPT. 3.2:153-158, 2002.

Sugiarto, dkk. 2007 Ekonomi Mikro: Sebuah Kajian Komprehensif. PT. Gramedia Pustaka Utama: Jakarta. 